\title{
A Comparison of Learning High School Modern Physics Topics Based on Two Different Curricula
}

\author{
Özlem Eryılmaz Muştü ${ }^{1 *}$, Ahmet İlhan Şen² \\ ${ }^{1}$ Department of Science Education, Aksaray University, Aksaray, Turkey, ${ }^{2}$ Department of Physics Education, Hacettepe University, Ankara, Turkey
}

*Corresponding Author: ozlemeryilmaz@gmail.com

\section{ABSTRACT}

In this study, the impacts of teaching modern physics topics according to textbooks that are prepared based on two different physics curricula implemented in Turkey on students' success, problem-solving skills, and attitudes were examined. The sample of the study consisted of 80 high school students studying in the $12^{\text {th }}$ grade. Within the scope of the study, the modern physics achievement test, the problem-solving inventory, and the attitude scale toward physics class were administered to the students. Data analyses revealed that course achievements and problem-solving skills of the students learning modern physics topics with the 2011 curriculum differ significantly in comparison to those of the students learning modern physics with the 2005 curriculum, yet there was no difference in terms of attitudes of the students. A good physics curriculum is expected to enhance students' attitudes toward physics Due to the complicated formulas, concepts, mathematical operations and calculations in modern physics topics, and students' attitude toward physics course may diminish after learning these topics. It can also be said that since the features of the 2011 curriculum have not been sufficiently reflected in the chapter, it has no influence on students' attitudes.

KEY WORDS: high school education; modern physics education; physics achievement; the problem-solving inventory; attitude

\section{INTRODUCTION}

$\mathbf{U}$ nlike classical physics, quantum physics, which is called modern physics, examines the world of subatomic particles and is based on a large number of formulas, equations, and mathematical calculations. In modern physics classes, fundamental theories and interpretations of quantum physics are usually discussed. It explains and interprets the quantum nature of electrons and photons (Cassens, 1994). It is generally harder than the mathematics and classical physics that students are used to. It is a field which is difficult to comprehend due to its abstract and difficult mathematical and conceptual structure. Understanding modern physics is of great importance not only to physicists but also to engineers and chemists. Along with the advances in electronics and nanotechnology, many devices in the engineering world can be used with the principles of quantum mechanics. At the same time, it has become more important to understand modern physics to enable people to catch up with developing technology and to make decisions about their businesses. For this reason, it is important for high school students to learn modern physics. However, as stated, modern physics topics are both difficult to understand due to their abstractness and difficulty, and these courses are also among the most difficult courses for teachers to teach (Çalışkan, 2002). In their study, McDermott and Redish (1999) examined the studies on physics teaching according to different categories. In their study, studies on modern physics concepts accounted for only $1 \%$ of all research.
Despite being an abstract subject involving microscopic concepts, modern physics requires advanced math skills. One of the approaches related to modern physics teaching is the quantitative approach in which students use mathematical algorithms and correlations to understand the concepts and to solve problems in this field (Sadaghiani, 2005). Another approach is the teaching approach in which the historical development of the theory is taken into consideration. In this approach, teaching is implemented by emphasizing the development and history of the theories, concepts, and experiments that led to the ideas of quantum physics and relativity. While some studies in the literature (Pospiech, 2000) emphasize that the mathematical structure of quantum physics theory overshadowed its philosophical aspect; some studies (Ireson, 1999) content that not only is the solution of mathematical problems but also the interpretation of calculations by the theories that pose problems for students. As far as students' problem-solving and apprehending, the concepts are concerned, it is known that although students can solve the problems using the mathematical formula in their textbooks, they have experienced difficulties in understanding the concepts of physics (Kim \& Pak, 2002). The primary reason that makes the teaching of quantum physics topics difficult in high schools is the inadequacy of students' mathematical knowledge (Strand, 1981). By the same token, students' solving mathematical operations correctly does not necessarily show that they understand the concepts of modern physics appropriately (Ke et al., 2005). In a study on 
how high school students think of modern physics concepts, it has been found that students visualize concepts such as photons and electrons in many unscientific forms (Mashadi \& Woolnough, 1999). Another study developed an approach that aimed to teach students the energy spectrum of different atoms, molecules, and solids, basic concepts such as the dimensions of the atom and mathematical calculations by choosing the concepts of state and orbital as central concepts. In this approach, it was noted that the stationary waves analogy was used when teaching modern physics concepts to students and a special computer program was used for the difficulties experienced in mathematical operations (Niedderer et al., 1996). Another study examined the students' misconceptions about the Schrödinger's wave equation and concluded that these misconceptions were caused by wrong generalizations and that despite the fact that the students were successful in mathematical operations, they failed to make qualitative explanations related to the questions (Singh et al., 2006). For students to learn quantum physics, teaching strategies in which the concepts are thought are needed (Singh, 2007).

It is seen that both the chronological order and the mathematical equations and formula are frequently addressed in textbooks when the topics of modern physics are taught in Turkey. Research (Eryılmaz \& Şen, 2010a; Eryılmaz \& Şen, 2010b) highlight some of the difficulties that high school students experience in learning physics. For example, they often cannot relate the concepts of modern physics such as photon, photoelectron, spectrum, photoelectric effect, and ionization energy with formulas. Similarly, many high school students have issues exploring, restructuring, interpreting, and comparing modern physics with their previous primary education. It is also expected that teachers have adequate understanding of the topics that should be taught. However, no studies about teachers in the field of modern physics education in Turkey have been found. When those on modern physics or quantum physics in Turkey are examined (Altunsoy, 2012; Çalışkan, 2002; Didiş, 2012; Kurt 2010; Özdemir, 2008; Özcan, 2009, Şimşek, 2009; Yeşildağ, 2009), it is seen that these are mostly conducted on teacher candidates. In his studies on teacher candidates, Şen (2002a; 2002b) examined the misconceptions and mistakes that they made in quantum physics. He reported that senior teacher candidates still tend to be hinging on classical analogies that used Newtonian physics instead of modern physics' way of thinking. He went on to note that their skills of understanding and expressing quantum physics were weaker than their mathematical skills.

While modern physics topics are being taught, it is important to ensure meaningful learning by concretizing concepts. This means bringing the visuality to the forefront and identifying the conceptual and mathematical difficulties that students encounter. However, it is obvious that there is not enough development in the field of modern physics teaching in Turkey and that modern physics topics are taught as the way they are given in the curriculum in high schools.
In 2005, together with the restructuring of secondary education institutions, teaching programs started to be renewed as well in Turkey. The program that was first implemented in 2005, has been revised in 2013. At the same time, a new physics curriculum was being developed. While the revised program was gradually phased out, the new physics teaching programs that were prepared were starting to be implemented. The exploration of the success and effectiveness of these two different physics curricula, which have been revised and put into practice, are important for the evaluation of the physics curricula. In literature, when the studies about physics curriculum are examined, it is seen that they make general evaluations about the curriculum. In this study, modern physics, which is one of the subjects that students are challenged with, is chosen and compared by investigating the success and effectiveness of two different teaching programs. This study is also important because it guides the new curricula to be prepared in the field of modern physics and the textbooks to be prepared for these curricula in physics education.

The main objective of this study is to investigate and evaluate the impact of the physics course curriculum that has been applied since 2011 and the teaching of modern physics topics with the $11^{\text {th }}$ grade textbook prepared based on this curriculum on learning, relative to the previous physics course curriculum revised in 2005 and the teaching conducted with the $12^{\text {th }}$ grade textbook prepared based on this curriculum. A result of this study is to make a contribution to the high school modern physics education literature.

The study in teaching the modern physics topics, the impacts of the modern physics courses conducted in accordance with the teaching curriculum that has been applied since 2011, on students' academic success, problem-solving skills, and attitudes will be explored relative to the courses conducted in accordance with the previous curriculum.

\section{METHODS}

In this study, a quantitative research method was used. The study, in which the effectiveness of modern physics teaching based on two different teaching programs and textbooks prepared according to these teaching programs was investigated and evaluated, was conducted in a causal comparison research model. To determine whether the curriculum and textbooks were more successful in teaching modern physics topics, impact assessment among causalcomparative research models was used. In causal-comparative studies, experiment and control groups are formed without intervention of the researcher because the research process starts after the occurrence of a situation or event (Cohen \& Manion, 1998; Fraenkel \& Wallen, 2006). In this study, the students of the experimental group were taught with the textbook prepared according to the $11^{\text {th }}$-grade physics curriculum while the students of the control group were taught with the $12^{\text {th }}$-grade textbook prepared according to the previous curriculum. 


\section{The Sample}

The sample for the study consists of a total of 80 students studying at the $11^{\text {th }}$ and $12^{\text {th }}$ grades of two different high schools in Aksaray Province. Since features such as the random assignment of subjects in the group and the homogeneity of the group are not controlled at the outset in causal-comparative studies (Büyüköztürk et al., 2008), the sample of this study was determined according to the purposive sampling method which is one of the non-random sampling methods. In the purposive sampling method, the groups are determined to depend on the purpose of the study.

\section{Data Collection Tools}

To determine the efficiency of the modern physics courses taught based on the textbooks prepared according to teaching programs, the modern physics achievement test (MPAT) developed by Author (2014), the problem-solving inventory (PSI) developed by Heppner and Petersan and translated into Turkish by Şahin et al. (1993) and the attitudes toward the Physics Course Scale (APCS) developed by Kocakülah and Kocakülah (2006) were administered to the students before and after the application as pre-test and post-test.

\section{Data Collection}

The study was executed simultaneously in two high schools. This part of the study was realized with the participation of a total of 80 students in two different high schools. First of all, the MPAT, the PSI, and the APCS were administered to all groups as pre-test. Then, students in each group were taught modern physics with the textbooks that were prepared based on the related curriculum. After teaching the modern physics topics, the inventories were re-administered as post-test. During the study, both the $11^{\text {th }}$ grade and the $12^{\text {th }}$ grade modern physics courses were taught by the same teacher.

\section{Data Analysis}

Data obtained in the study were analyzed through SPSS 17 for Windows software. In the study, the data obtained from the answers given by the 11th and 12th-grade students to the achievement test, PSI, and attitude scale were used. First of all, the obtained data were organized and made ready for analysis. After the suitability of the data for parametric tests was checked, a one-way multivariate analysis of covariance (MANCOVA) which is among the multivariate statistical methods was determined to be used given the number and type of variables (Tabachnick and Fidell, 2007). In MANCOVA, the Bonferroni correction was applied to control type-1 error and the $\alpha$ value was divided by three because the number of dependent variables was three, and the significance level was examined as $\alpha=0.016$ (Abdi, 2007).

In the second part of the study, the total score averages of the data obtained from the answers are given to the questionnaire items by the experts and physics teachers were calculated and analyzed and interpreted by making relative interpretation according to the range method. In the relative evaluation according to the range method, the difference between the maximum and minimum scores is calculated, and the score zones were found by dividing this difference by the score range. The mean scores were interpreted by making a 3-point Likert score range as in the questionnaire used, after the maximum and minimum scores had been detected for each item. In this part, explanations of the teachers and experts when they responded no or partially to the questionnaire items were also addressed.

\section{FINDINGS}

In this section, findings of the inferential statistical results related to the study are presented.

\section{Findings Related to the Study}

The impacts of the modern physics education taught in line with the 11th-grade curriculum on students' modern physics course achievement, problem-solving skills, and attitudes toward the physics course relative to the modern physics education taught in line with the previous 12th-grade curriculum.

After the assumptions of the MANCOVA were checked, a MANCOVA analysis was run to test the general problem of the study and the hypothesis related to this. The preparation of the data related to this part of the study for the analysis, examination of the premises necessary for MANCOVA, descriptive and inferential statistical results related to the data were entirely presented in the thesis of Eryllmaz (2014). Results of MANCOVA run for testing the hypothesis are presented in Table 1.

When the MPAT, PSI, and APCS scores are examined in Table 1, there is a significant difference between modern physics courses taught according to the curriculum that is currently applied (Group 1) and modern physics courses taught according to the 2005 curriculum (Group 2) in terms of mean scores for attitudes toward physics course, problem solving skills, and modern physics course achievement.

The eta-squared value $\left(\eta^{2}\right)$, which is also called impact size, shows how much of the total variance in the dependent variable is explained by the independent variable or factor. Eta-squared

\begin{tabular}{|c|c|c|c|c|c|c|c|}
\hline Variable & Wilks' Lambda & $\mathbf{F}$ & Hip. df. & Error df. & Sig. & Multiple eta squared & Statistical power \\
\hline Intercept & 0.480 & 26.324 & 3 & 73 & 0.000 & 0.520 & 1.00 \\
\hline MPAT pre-test & 0.872 & 3.577 & 3 & 73 & 0.018 & 0.128 & 0.769 \\
\hline APCS pre-test & 0.930 & 1.835 & 3 & 73 & 0.148 & 0.070 & 0.458 \\
\hline APCS pre-test & 0.981 & 0.484 & 3 & 73 & 0.695 & 0.019 & 0.143 \\
\hline Group & 0.351 & 44.961 & 3 & 73 & 0.000 & 0.649 & 1.000 \\
\hline
\end{tabular}


$\left(\eta^{2}\right)$ takes values between 0.00 and 1.00 , and eta-squared values at the $0.01,0.06$, and 0.14 levels are interpreted as small, medium, and large impact, respectively (Green et al., 1997). In the study, the inter-group eta-squared value $\left(\eta^{2}\right)$ was found to be 0.649 . This result indicates that approximately $65 \%$ of the total variance in the dependent variable stems from the variation in the curriculum, controlling for the covariates.

The mean scores corrected according to the covariates (MPAT, PSI, and APCS Pre-test mean scores) of post-test mean scores of MPAT, PSI, and APCS are presented in Table 2.

When Table 2 is examined, it is seen that there is not much variation in post-test mean scores for MPAT, PSI, and APCS controlling for the pre-test mean scores for MPAT, PSI, and APCS between the groups. Depending on this, there is no big difference between the post-test mean scores of the groups either.

ANCOVA results of the post-test scores for MPAT, PSI, and APCS corrected according to the covariates are presented in Table 3.

When Table 3 is examined, it is seen that students' post-test scores for problem-solving skills and modern physics course

Table 2: Post-test mean scores of MPAT, PSI, and APCS according to the groups and corrected mean scores

\begin{tabular}{llccc}
\hline Variable & Group & $\mathbf{n}$ & Mean & Corrected mean \\
\hline MPAT post-test & Group 1 & 40 & 19.42 & 19.26 \\
& Group 2 & 40 & 12.67 & 12.86 \\
PSI post-test & Group 1 & 40 & 148.87 & 149.79 \\
& Group 2 & 40 & 131.42 & 130.50 \\
APCS post-test & Group 1 & 40 & 97.32 & 97.03 \\
& Group 2 & 40 & 92.67 & 92.96 \\
\hline
\end{tabular}

achievement separately demonstrate significant differences according to the curricula (groups) whereas the attitudes toward physics courses do not, controlling for the covariates. When it comes to the impact size value, it can be argued that it is large in MPAT post-test while small in APCS post-test.

ANCOVA results of the MPAT corrected post-test scores that are corrected according to the covariates are given in Table 3 . When Table 3 is examined, it is found that a statistically significant difference exists between the modern physics course achievements of the students who are taught physics according to the 2011 and 2005 curricula, controlling for the covariates. $\eta^{2}$ was analyzed to find the impact size of the independent variable on three dependent variables, and it was seen that there is a large impact size $\left(\eta^{2}=0.602\right)$ on modern physics achievement. This value shows that the change implemented in the curriculum has a $60 \%$ significant impact on students' modern physics achievements.

The multiple comparison test results of MPAT post-test mean values are presented in Table 4.

When Table 4 is examined, according to the Bonferroni test result, it is concluded that the change implemented in modern physics course education is statistically significant in modern physics course achievement to mean scores and that an increase in favor of the 2011 curriculum has been experienced. It can be claimed that the students who were taught modern physics courses according to the 2011 curriculum have higher achievement in comparison to the students who were taught modern physics courses according to the 2005 curriculum.

ANCOVA results of the PSI corrected post-test scores corrected according to the covariates are given in Table 3 . When Table 3 is examined, it is found that a statistically significant difference

Table 3: ANCOVA results of the post-test scores corrected according to the covariates

\begin{tabular}{|c|c|c|c|c|c|c|c|c|}
\hline $\begin{array}{l}\text { Source of } \\
\text { the variance }\end{array}$ & Dependent variable & Sum of squares & df. & Mean of squares & $F$ & Sig. & Partial eta-squared & Statistical power \\
\hline \multirow{3}{*}{$\begin{array}{l}\text { MPAT } \\
\text { pre-test }\end{array}$} & APCS post-test & 48.498 & 1 & 48.498 & 0.139 & 0.710 & 0.002 & 0.066 \\
\hline & APCS post-test & 530.602 & 1 & 530.602 & 1.712 & 0.195 & 0.022 & 0.253 \\
\hline & MPAT post-test & 63.456 & 1 & 63.456 & 9.472 & 0.003 & 0.112 & 0.859 \\
\hline \multirow{3}{*}{$\begin{array}{l}\text { APCS } \\
\text { pre-test }\end{array}$} & APCS post-test & 1334.195 & 1 & $1,334.195$ & 3.829 & 0.054 & 0.049 & 0.489 \\
\hline & APCS post-test & 171.594 & 1 & 171.594 & 0.554 & 0.459 & 0.007 & 0.114 \\
\hline & MPAT post-test & 1.046 & 1 & 1.046 & 0.156 & 0.694 & 0.002 & 0.068 \\
\hline \multirow{3}{*}{$\begin{array}{l}\text { APCS } \\
\text { pre-test }\end{array}$} & APCS post-test & 7.221 & 1 & 7.221 & 0.021 & 0.886 & 0.000 & 0.052 \\
\hline & APCS post-test & 283.657 & 1 & 283.657 & 0.915 & 0.342 & 0.012 & 0.157 \\
\hline & MPAT post-test & 3.054 & 1 & 3.054 & 0.456 & 0.502 & 0.006 & 0.102 \\
\hline \multirow[t]{3}{*}{ Group } & APCS post-test & 310.311 & 1 & 310.311 & 0.891 & 0.348 & 0.012 & 0.154 \\
\hline & APCS post-test & 6976.318 & 1 & $6,976.318$ & 22.512 & 0.000 & 0.231 & 0.997 \\
\hline & MPAT post-test & 761.038 & 1 & 761.038 & 113.599 & 0.000 & 0.602 & 1.000 \\
\hline \multirow[t]{3}{*}{ Error } & APCS post-test & $26,133.956$ & 75 & 348.453 & & & & \\
\hline & APCS post-test & $23,241.836$ & 75 & 309.891 & & & & \\
\hline & MPAT post-test & 502.452 & 75 & 6.699 & & & & \\
\hline \multirow[t]{3}{*}{ Total } & APCS post-test & $750,046.00$ & 80 & & & & & \\
\hline & APCS post-test & 1.601 .708 .00 & 80 & & & & & \\
\hline & MPAT post-test & 22.092 .00 & 80 & & & & & \\
\hline
\end{tabular}




\begin{tabular}{|c|c|c|c|c|c|c|c|}
\hline \multirow[t]{2}{*}{ Dependent variable } & \multirow[t]{2}{*}{ (I) Group } & \multirow[t]{2}{*}{ (J) Group } & \multirow[t]{2}{*}{ Difference of means (I-J) } & \multirow[t]{2}{*}{ Standard error } & \multirow[t]{2}{*}{ Sig. } & \multicolumn{2}{|c|}{ Confidence Interval } \\
\hline & & & & & & Lower limit & Upper limit \\
\hline \multirow[t]{2}{*}{ MPAT Post-test } & Group 1 & Group 2 & 6.372 & 0.598 & 0.000 & 5.181 & 7.563 \\
\hline & Group 2 & Group 1 & -6.372 & 0.598 & 0.000 & -7.563 & -5.181 \\
\hline
\end{tabular}

MPAT: Modern physics achievement test

\begin{tabular}{|c|c|c|c|c|c|c|c|}
\hline \multirow[t]{2}{*}{ Dependent variable } & \multirow[t]{2}{*}{ (I) Group } & \multirow[t]{2}{*}{ (J) Group } & \multirow[t]{2}{*}{ Difference of means (I-J) } & \multirow[t]{2}{*}{ Standard error } & \multirow[t]{2}{*}{ Sig. } & \multicolumn{2}{|c|}{ Confidence interval } \\
\hline & & & & & & Lower limit & Upper limit \\
\hline \multirow[t]{2}{*}{ PSI post-test } & Group 1 & Group 2 & 19.293 & 4.066 & 0.000 & 11.193 & 27.394 \\
\hline & Group 2 & Group 1 & -19.293 & 4.066 & 0.000 & -27.394 & -11.193 \\
\hline
\end{tabular}

PSI: Problem-solving inventory

exists between the problem-solving skills of the students who are taught physics according to the 2011 and 2005 curricula, controlling for the covariates. The impact size of the dependent variable on problem-solving skills is large, and the value is $\eta^{2}=0.231$. This value shows that the significant impact of the change in the curriculum on students' problem-solving skills is $23 \%$.

The multiple comparison test results of PSI post-test scores are presented in Table 5 .

When Table 5 is examined, according to the Bonferroni test results, it is concluded that the change implemented in modern physics course education is statistically significant in students' problem-solving skills and that an increase in favor of the 2011 curriculum has been experienced. It can be claimed that the students who were taught modern physics courses according to the 2011 curriculum had better problem-solving skills in comparison to the students who were taught modern physics courses according to the 2005 curriculum.

ANCOVA results of the APCS corrected post-test scores corrected according to the covariates are given in Table 3 . When Table 3 is examined, no statistically significant difference was found between the mean scores of the attitudes toward the physics course of students who are taught physics according to the 2011 and 2005 curricula, controlling for the covariates. The $\eta^{2}$ value was analyzed to find the impact size of the independent variable on the dependent variable, and it was seen that the impact size on attitudes toward physics course is small with a value of $\eta^{2}=0.012$. This value shows that the difference between the modern physics course curricula has a $1.2 \%$ and statistically insignificant impact on students' attitudes toward physics course.

\section{DISCUSSION}

It is seen that students in both groups succeeded in the pretest of the MPAT without a significant difference between their mean scores. It is assumed that the main reason for this success is that the topics are taught to the students by the auxiliary course institutions they enroll to prepare for the university entrance exam. Furthermore, similar modern physics topics are taught in the $10^{\text {th }}$ grade in the 2011 chemistry curriculum. It is seen that students in both groups enhanced their achievements at the post-test of the MPAT, yet, the students at the 2011 curriculum group are more successful than the students in the previous curriculum group. The most basic feature of the 2011 curriculum is the existence of skills that are expected to be processed in the knowledge gains of each chapter. It is concluded that because this skill that needs to be in the modern physics chapter is not at an adequate level, students' problem-solving skills demonstrate differences relative to the previous curriculum, yet this difference is not large since these skills could not be processed sufficiently.

As it is frequently emphasized in literature, it is known that students do not develop a positive attitude toward courses that they find abstract and hard, and cannot understand. Physics is a primary example of these courses (Demirci, 2004). It is thought that because modern physics is one of the hardest topics of physics course, no significant difference was seen between the students' attitudes toward the course before and after the modern physics education. A good physics curriculum is expected to enhance students' attitudes toward physics (Zacharia, 2003). Due to the complicated formulas, concepts, mathematical operations, and calculations in modern physics topics, students' attitude toward physics courses may diminish after learning these topics. It can also be said that since the features of the 2011 curriculum have not been sufficiently reflected in the chapter, it has no influence on students' attitudes.

\section{CONCLUSIONS}

In this study, it is aimed to investigate and evaluate the impact of the teaching of the current physics course curriculum that has been applied since 2011 and the modern physics topics of the $11^{\text {th }}$-grade physics textbook prepared in line with this curriculum in comparison to the teaching of the current physics 
course curriculum that has been applied since 2005 and the modern physics topics of the $12^{\text {th }}$-grade physics textbook prepared in line with this curriculum. In this study, which consists of two parts, the impacts of the courses, in which these curricula are applied, and the textbooks prepared according to these curricula are used, on students' academic achievement, problem-solving skills, and attitudes in the teaching of modern physics topics were investigated.

In the study, first, the MPAT, the PSI, and the attitudes toward physics course scale were applied as a pre-test to identify students' preparedness level and pre-learning. As a result of the pre-tests, it was seen that preparedness level and pre-learning of the students participated in the study were the same. After the modern physics courses, differences were identified in students' attitudes toward physics course, problem-solving skills, and modern physics achievement in the courses conducted in line with the 2011 curriculum and the courses conducted in line with the previous curriculum.

When the results were analyzed as to students' modern physics achievements, no significant difference was found in students' modern physics achievement in the courses conducted in line with the current curriculum in comparison to the previous curriculum. It was determined that students who are taught with 2011 curriculum and textbook were more successful in modern physics topics in comparison to the previous curriculum. This result is in parallel with the studies by Çalışkan (2002), Tuncer and Eryılmaz (2002), Şimşek (2009), and Yıldız (2009) in terms of the enhancement of student achievement with the curriculum.

When the results were analyzed in terms of students' problem-solving skills, significant differences were found between students' problem-solving skills at the end of the courses conducted in the 2011 curriculum in comparison to the previous curriculum. It was determined that the problemsolving skills of the students who are taught with 2011 curriculum and textbook were higher in comparison to the 2005 curriculum.

When the results were analyzed in terms of students' attitudes toward physics course, no significant difference was found in students' attitudes toward physics courses at the end of the courses conducted in the 2011 curriculum in comparison to the 2005 curriculum. It was concluded that there is no significant enhancement between the students taught with the 2011 curriculum and textbook, and the students taught with the 2005 curriculum and textbook in terms of attitudes toward physics course. This result shows, as in Aycan and Yumuşak's (2003) study, that students' attitudes do not enhance in the topics they have difficulty in understanding.

\section{ACKNOWLEDGMENT}

This article was produced from the doctoral thesis prepared by first author at the Hacettepe University Institute of Educational Sciences under the supervision of the second author.

\section{REFERENCES}

Abdi, H. (2007). Bonferroni and sidak correction for multiple comparisons. In: Salkind, N. (Ed.), Encyclopedia of Measurement and Statistics. Thousand Oaks, CA: SAGE. p103-107. Available from: http://www. cogsci.ucsd.edu/ dgroppe/STATZ/Abdi-Bonferroni2007-pretty.pdf. [Last accessed on 2019 Sep 17].

Altunsoy, S. (2012). Fen ve Teknoloji Öğretmen Adaylarının Üstbilişsel Stratejileri Kullanmalarının Özel Görelilik Teorisi Konusundaki Başarllarl ve Kuantum Fiziğine Yönelik Tutumlarl Üzerine Etkisi. [The Effect of Using Metacognitive Strategies on Prospective Science and Technology Teachers' Achievements in Special Theory of Relativity and Attitudes towards Quantum Physics]. Master's Thesis. Ankara: Gazi University, Institute of Sciences. Available from: http://www.acikarsiv. gazi.edu.tr/index.php?menu=2\&secim=10\&YayinBIK=8577. [Last accessed on 2019 Sep 17].

Aycan, Ş., \& Yumuşak, A. (2003). Lise Fizik Müfredatındaki Konuların Anlaşılma Düzeyleri Üzerine bir Araştırma. [A Research on the Level of Understanding of Subjects in High School Physics Curriculum]. Milli Eğitim Dergisi. p159. Available from: https://www.dhgm.meb.gov.tr/ yayimlar/dergiler/Milli_Egitim_Dergisi/159/aycan-yumusak.htm. [Last accessed on 2019 Sep 09].

Büyüköztürk, Ş., Çakmak, E., Akgün, Ö.E., Karadeniz, Ş., \& Demirel, F. (2008). Bilimsel Araştırma Yöntemleri [Scientific Research Methods]. Ankara: Pegem Akademi.

Çalışkan, S. (2002). Kuantum Fiziği Dersi Öğretim Programı Tasarısı: Harmonik Osilatör Örneği. [Curriculum Design of Quantum Physics Course: The Harmonic Oscillator Case]. (Master's Thesis). İzmir, Turkey: Dokuz Eylül University, Institute of Social Sciences.

Cassens, H. (1994). Entwicklung von Potentialtopfmodellen für die Behandlung von Molekülen und Festkörpern im Quantenphysikunterricht [Development of potential well models for the treatment of molecules and solids in quantum physics teaching] (Doctoral Dissertation). Bremen Uni, FB1, Bremen. Available from: http://www.idn.uni-bremen. de/pubs/Niedderer/1994-Diss-HC.pdf. [Last accessed on 2019 Sep 01].

Cohen, L., \& Manion, L. (1998). Research Methods in Education. $4^{\text {th }}$ ed. London: Routledge.

Demirci, N. (2004). Students' attitudes toward introductory physics course. Hacettepe University Journal of Education, 26, 33-40.

Didiş, N. (2012). Investigation of Undergraduate Students' Mental Models about the Quantization of Physical Observables (Doctoral Dissertation). Ankara: Middle East Technical University, Institute of Sciences. Available from: http://www.etd.lib.metu.edu.tr/upload/12614316/index. pdf. [Last accessed on 2019 Jun 06].

Eryılmaz, Ö. (2014). Lise Modern Fizik Konularının iki Farklı Öğretim Programına Göre Öğrenilme Durumlarının Karşılaştırılması. [Comparison of the Learning Status of High School Modern Physics Subjects Taught in Line with Two Different Teaching Programs]. (Doctoral Dissertation). Ankara, Turkey: Hacettepe University, Institute of Educational Sciences. Available from: http://www.openaccess. hacettepe.edu.tr:8080/xmlui/handle/11655/1915. [Last accessed on 2019 Jun 01].

Eryılmaz, Ö., \& Şen, A.İ. (2010a). Ortaöğretim 12. Sinıf Öğrencilerinin Modern Fizik Konusundaki Kavramlarının Kavram Haritalar ile Belirlenmesi. [Determining the Concepts of $12^{\text {th }}$ Grade Students in Modern Physics with Concept Maps]. İzmir: Ulusal Fen ve Matematik Eğitimi Kongresi, Bildiri özet Kitab1. p36.

Eryılmaz, Ö., \& Şen, A.İ. (2010b). Ortaöğretim 12. Sınıf Öğrencilerinin Modern Fizik Konusundaki Düşüncelerinin Kavram Haritalarl ile Tespit Edilmesi. [Determination of $12^{\text {th }}$ Grade Students' thoughts on Modern Physics with Concept Maps]. Türk Fizik Derneği 27. İstanbul: Uluslararası Fizik Kongresi, Bildiri özet kitab1. p363.

Fraenkel, R.M. \& Wallen, N.E. (2006). How to Design and Evaluate Research in Education. $6^{\text {th }}$ ed. New York: McGraw- Hill International Edition.

Green, S.B., Salkind, N.J., \& Akey, T.M. (1997). Using SPSS for Windows: Analyzing and Understanding Data. New York: Prentice Hall.

Ireson, G. (1999). A multivariate analysis of undergraduate physics students' conceptions of quantum phenomena. European Journal of Physics, 20(3), 193-199. 
Ke, J.L., Monk, M., \& Duschl, R. (2005). Learning introductory quantum physics: Sensori-motor experiences and mental models. International Journal of Science Education, 27(13), 1571-1594.

Kim, E., \& Pak, S.J. (2002). Students do not overcome conceptual difficulties after solving 1000 traditional problems. American Journal of Physics, $70,759-765$.

Kocakülah, M., \& Kocakülah, A. (2006). Öğrencilerin Yapılandırmacı Öğrenme Kuramına Dayalı Olarak Işlenen Fizik Dersine Yönelik Tutumları. [Attitudes of Students towards Physics Course Based on Constructivist Learning Theory]. Proceedings of $6^{\text {th }}$ International Educational Technology Conference. Vol. 2. Famagusta, North Cyprus. p1160-1167. Available from: http://www.iet-c.net/publication_folder/ ietc/ietc2006.pdf. [Last accessed 2019 May 01].

Kurt, H.S. (2010). Kuantum Fiziğinde Kullanılan Metaforların Öğrencilerin Fizik Algisı Üzerine Etkisi. [The Effects of Metaphors used in Quantum Physics on Students' Perception of Physics]. (Master's Thesis). Ankara, Turkey: Gazi University, Institute of Educational Sciences.

Mashadi, A., \& Woolnough, B. (1999). Insights into students' understanding of quantum physics: Visualizing quantum entities. European Journal of Physics, 20(6), 511-516.

McDermott, L., \& Redish, E. (1999). Resource letter per-1: Physics education research. American Journal of Physics, 67, 755-767.

Niedderer, H., Bethge, T., Cassens, H., \& Petri, J. (1997). Teaching Quantum Atomic Physics in College and Research Results about a Learning Pathway. Vol. 399. Proceedings of AIP Conference Proceedings. p659.

Özcan, Ö. (2009). Kuantum Mekaniği Ve Görelilik Öğretiminde Karşılaşılan Kavramsal ve Matematiksel Zorlukların Karşılaștırılması. [Investigation of Conceptual and Mathematical Difficulties in Learning Quantum Mechanics and Relativity]. (Doctoral Dissertation). Ankara, Turkey: Hacettepe University, Institute of Sciences.

Özdemir, E. (2008). Kuantum Fiziğinde Belirsizlik Ilkesi: Hibrit Yaklașımla Öğretimin Akademik Başarlya Etkisi. [Uncertainty Principle of Quantum Physics: Effects of Hybrid Teaching on Academic Achievement]. (Master's Thesis). İzmir: Dokuz Eylül University, Institute of Educational Sciences.

Pospiech, G. (2000). Uncertainty and complementarity: The heart of quantum physics. Physics Education, 35(6), 393-399.

Sadaghiani, H.R. (2005). Conceptual and Mathematical Barriers to Students Learning Quantum Mechanics (Doctoral Dissertation). Ohio: The Ohio State University. Available from: https://www.etd.ohiolink.edu/!etd. send_file?accession $=$ osu1123878116\&disposition=inline. [Last accessed on 2019 Sep 15].

Şahin, N., Şahin, N.H., \& Heppner, P.P. (1993). Psychometric properties of the problem solving inventory in a group of Turkish university students. Cognitive Therapy and Research, 17(4), 379-396.

Şen, A.İ. (2002a). Fizik öğretmen adaylarının kuantum fiziğinin temeli sayılan kavram ve olayları değerlendirme biçimleri [Pre-service physics teachers' ways of evaluating concepts and events that are considered the basis of quantum physics]. Journal of BAU Institute of Science and Technology, 4(1), 76-85.

Şen, A.İ. (2002b). Concept map as a research and evaluation tool to assess conceptual change in quantum physics. Science Education International, $13,14-24$.

Şimşek, E. (2009). Karma Öğrenmenin Fizik Öğretmen Adaylarının Bilgisayar, Internet ve Web Tabanlı Ögretime Yönelik Tutumları. [The Effect of Blended Learning on the Attitudes of the Physics Pre-service Teachers Toward the Computer, Internet and Web-based Education]. (Master's Thesis). Ankara, Turkey: Hacettepe University, Institute of Sciences.

Singh, C. (2007). Student Difficulties with Quantum Mechanics Formalism. Vol. 883. Proceedings of the Physics Education Research Conference. p185-188. Syracuse, American Institute of Physics (AIP) Conference Proceedings, Melville New York. Available from: https://www. aip.scitation.org/doi/abs/10.1063/1.2508723. [Last accessed on 2019 Sep 16].

Singh, C., Belloni, M., \& Christian, W. (2006). Improving students' understanding of quantum mechanics. Physics Today, 59(8), 43-49.

Strand, J. (1981). Quantum physics for beginners. Physics Education, 16(2), 88-92.

Tabachnick, B.G., \& Fidell, L.S. (2007). Using Multivariate Statistics. $5^{\text {th }}$ ed. Boston: Pearson Education.

Tuncer, Y., \& Eryılmaz, A. (2002). Yoğun Fizik Müfredat Proğraminin Lise Öğrencilerinin Fizik Başarisina Etkisini Inceleme [Examining the Effect of Physics Curriculum on the Success of Physics of High School Students]. Proceedings of $5^{\text {th }}$ National Science and Mathematics Education Congress, No. 136. Ankara: Middle East Technical University (METU). Available from: http://www.old.fedu.metu.edu.tr/ufbmek-5/ ozetler/d136.pdf. [Last accessed on 2019 Sep 15].

Yeşildağ, F. (2009). Modern Fizik Öğretiminde Öğrencilerin Çoklu Modsal Betimlemeleri Algllamaları ve Modsal Betimlemelerle Hazırladiklar Yazma Aktivitelerini Değerlendirme Sürecinin Öğrenmeye Etkisi. [Students Understanding of Multi Modal Representations and the Effect of Writing Evaluation Process in Learning College Modern Physcis Units]. (Master's Thesis). Erzurum, Turkey: Atatürk University, Institute of Sciences.

Yıldız, A. (2009). Üniversite Öğrencilerinin Kuantum Fiziği Konularını Anlama Düzeyleri ve Öğrenme Amaçlı Yazma Aktivitelerinin Akademik Başartya Etkisi. [College Students' Understanding Level of Quantum Physics and the Effect of Using Writing to Learn Activities on Academic Achievement]. (Unpublished Doctoral Dissertation). Erzurum., Turkey: Atatürk University, Institute of Sciences.

Zacharia, Z. (2003). Beliefs, attitudes and intentions of science teachers regarding the education use of computer simulations and inquiry-based experiments in physics. Journal of Research in Science Teaching, 40(8), 792-823. 